\title{
Edição, recepção e mobilidade do romance Les mystères de Paris no Brasil oitocentista*
}

\author{
Publishing, reception and mobility \\ of the novel Les Mystères de Paris \\ in Nineteenth-Century Brazil ${ }^{\star \star}$
}

\author{
NELSON SCHAPOCHNIK \\ Professor da Faculdade de Educação, Universidade de São Paulo \\ Doutor em História Social, Universidade de São Paulo (USP) \\ Avenida da Universidade, 308. Butantã, \\ São Paulo (SP), CEP 05508-040 \\ nschapo@uol.com.br
}

RESUMO Este ensaio procura traçar a história editorial e o sucesso comercial do romance Les Mystères de Paris, de Eugène Sue, por meio da análise dos distintos padrões de impressão (folhetim e livro), a sua recepção e as suas traduções. Paralelamente ao exame das formas de circulação e comercialização do livro, verificou-se a sua difusão no acervo de bibliotecas e gabinetes de leituras, bem como a sua adaptação para o teatro e ópera.

Palavras-chave edição, recepção, mobilidade

* Artigo recebido em: 25/04/2010. Aprovado em: 04/06/2010.

** Este ensaio foi escrito sob os auspícios de uma bolsa de pesquisador sênior concedida pela Fundação Calouste Gulbenkian (FCG) junto ao Real Gabinete Português de Leitura do Rio de Janeiro (RGPL-RJ). À FCG e ao RGPL$\mathrm{RJ}$, pois, os meus agradecimentos. 
ABSTRACT This essay attempts to trace the publishing history and the commercial success of the novel Les Mystères de Paris, Eugène Sue, through the analysis of the different printing standards (feuilleton and book), its reception and its translations. Addition to the examination of the forms of distribution and commercialization of the book, it was checked its diffusion in the collection of public libraries and subscription libraries, as well as its adaptation to the drama and opera.

Keywords publishing, reception, mobility

\section{História, caricatura e cânone literário}

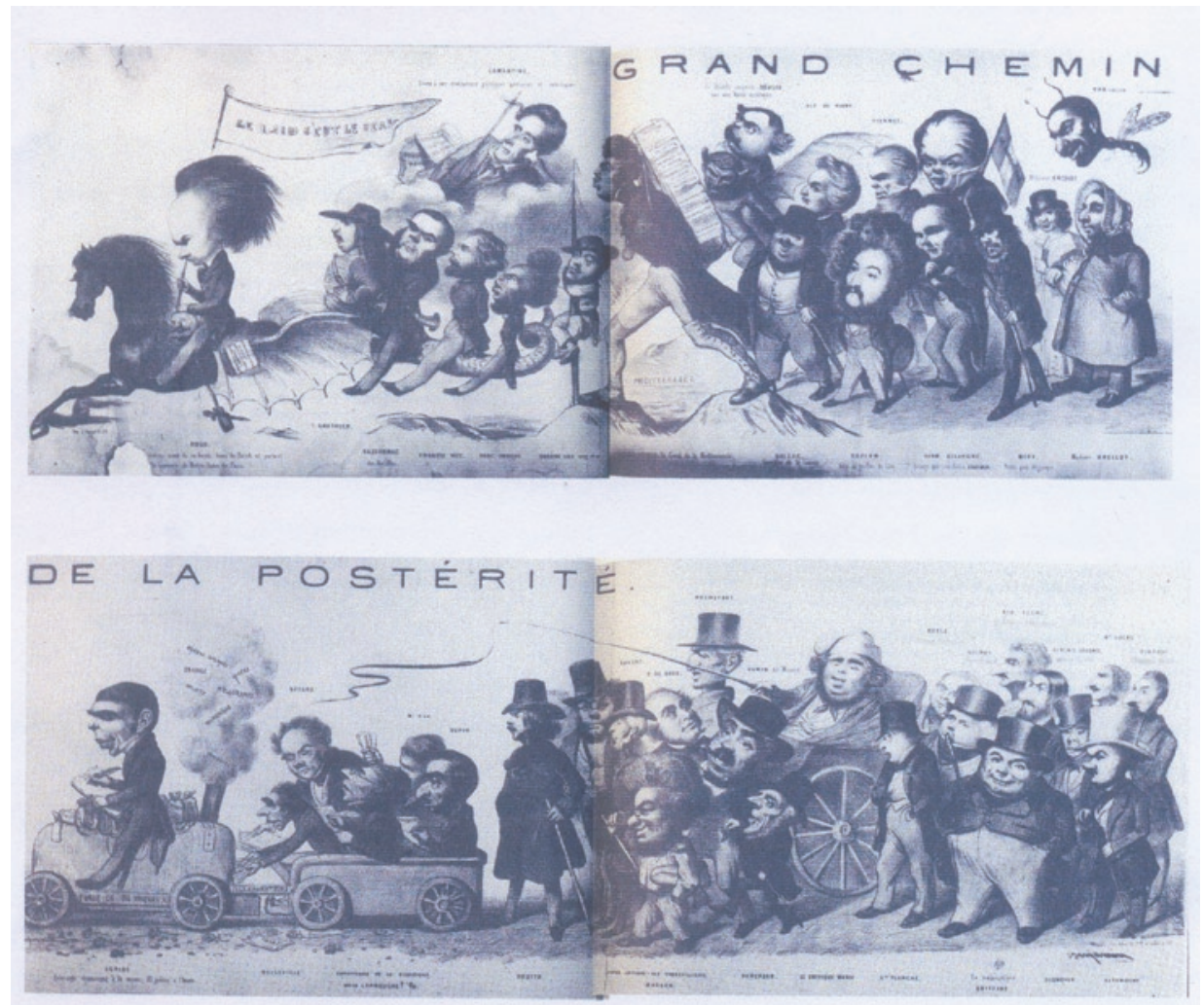

Imagem 1: Le grand chemin de la postérité, Benjamin Roubaud. (Maison Victor Hugo)

Em 1842, o caricaturista francês Benjamin Roubaud mandou imprimir na casa Aubert (Paris) uma série de três litografias, sendo que duas delas foram dedicadas à arte lírica, ao teatro e à dança. A terceira e mais célebre 
delas, intitulada Le grand chemin de la postérité, foi dedicada aos escritores. ${ }^{1}$ A gravura de grandes dimensões $(138,5 \times 26,5 \mathrm{~cm})$ e traços notadamente satíricos fixava uma perspectiva bastante curiosa. Usando alguns procedimentos característicos deste tipo de figuração, como a desproporção entre o tronco e a cabeça, valorizando alguns traços fisionômicos e agregando legendas eventualmente desconcertantes que remetiam a um trocadilho com o nome do escritor ou de um personagem, ou ainda, um aspecto de uma obra.

Na primeira prancha, a representação dos escritores franceses se dá sob a forma de um cortejo liderado por Victor Hugo que sentado num híbrido de cavalo e dragão, empunha em uma das mãos uma bandeira com o mote dos escritores românticos: Le laid, c 'est beau (O feio é belo), a outra mão encontra-se apoiada num crânio, de onde pende uma corda com uma pena de escrever e um frasco de tinta. Seguem-no na cauda do dragão, Théophile Gauthier, Cassagnac, Frances Wey, Paul Fouché. Depois aparecem perfilados Eugene Sue ("sangue e água"), Frédéric Soulié ("o Diabo carrega Soulié para o cume da montanha"), Alexandre Dumas ("o galo do Mediterrâneo republicando reedições de suas impressões de viagem"), Honoré de Balzac ("o inventor da mulher de trinta anos"), León Gozlan ("cabeça e garras de leão"), Jules Méry, Alfred Vigny, Alphonse Karr ("Karicarura"), Monsieur e Madame Ancelot (ele usando uma touca feminina e ela com um chapéu masculino sobre a cabeça). Pairando sobre o grupo, Alphonse de Lamartine, com um olhar perdido em crispações, segura uma cruz e tem ao seu lado um pacote com 100.000 francos, ao qual Roubauld acrescentou a legenda "entregue às suas meditações políticas, poéticas e católicas".

A segunda prancha é ainda mais inusitada. Eugene Scribe ("fabricante dramático à vapor, trinta peças por hora") conduz uma locomotiva que avança alimentada por textos de operetas, vaudevilles, dramas, comédias e melodramas, gêneros produzidos pelos ocupantes do pequeno vagão, a saber, Anne Duveyrier Mélesvilles, Bayard, Pierre François Adolphe Carmouche, M. e Dupin. Fechando o séquito de escritores, aparecem caminhando Rosier, Michel Masson, Paul de Kock, Charles Desnoyer, Théophile Marion Du Mersan e outros tantos.

Roubaud perenizou uma imagem que contrasta com as classificações dedutivas dos estilos que ainda vigoram nos manuais de estudos literários. A matéria representada passa ao largo daqueles lugares-comuns que

1 Benjamin Roubaud (1811-1847) foi pintor, caricaturista e litógrafo. Participou de alguns Salões nos anos 30 com pinturas de paisagens, naturezas-mortas e retratos. A partir dos anos 40 , destacou-se como desenhista e caricaturista com importante participação nas revistas e jornais do período, tais como: L'Illustration, Le Charivari, La Caricature, Le Panthéon Charivarique e Galerie de La Presse. Suas caricaturas e retratos das principais figuras da Monarquia de Julho constituem uma base documental de primeira ordem. Atualmente, a gravura Le grand chemin de la postérité encontra-se depositada na Maison Victor Hugo (Place des Vosges, Paris). 
mencionam o conflito entre o racional e o irracional, a clareza e ordem dos clássicos e a imaginação e impulsividade dos românicos, os vacilos entre a fé e a crença no progresso, o desejo de mudança social. Tampouco, alguma referência ao mal du siècle, à angústia ou à melancolia. ${ }^{2}$

$\mathrm{Na}$ contramão dos críticos e dos juízos que apelavam para a exemplaridade moral e acabamento estético das obras literárias o tal "grande caminho da posteridade", isto é, a entronização daquela galeria de escritores parecia estar associada ao sucesso financeiro obtido na comercialização dos textos. Aliás, de textos como se viu de gêneros e de natureza variada que passaram a circular nos diferentes espaços que emergiram na França pós-Napoleônica, tais como os gabinetes de leitura, os quiosques, as bibliotecas, os teatros e as casas de espetáculo, sem deixar de associálos aos novos modos de distribuição que promoveram uma inequívoca alteração nos padrões de consumo dos artefatos textuais. Neste caso, o sucesso decorrente do aluguel e da vendagem das obras, ou ainda das adaptações dos textos para o palco, também permitiria ler a prosperidade como um equivalente à posteridade. Portanto, o cortejo representado por Roubaud punha ênfase naquela dimensão por muito recalcada, que em nome do sublime e do "gênio", obscurecia as estreitas relações do fazer literário com o mercado e as possibilidades de profissionalização dos escritores. Não parece equivocado afirmar que o gravurista abordava o mesmo tema alcunhado de "literatura industrial"3 por Saint-Beauve nas páginas da Revue des Deux Mondes, só que de uma perspectiva positiva. Vale recordar que a expressão empregada revelava o desdém do crítico por um tipo de literatura que estava inexoravelmente ligada à musa industrial, isto é, uma forma de produção manufatureira de ficção que ele acreditava ser despojada de valor literário, pois estava à mercê da encomenda feita pelo proprietário do jornal, das imposições do editor e, não raro, dos insistentes apelos do público leitor.

Como se sabe, as diversas histórias literárias acabaram por abonar a avaliação de Saint-Beauve e, em grande parte, contribuíram para o banimento de muitos escritores que embora tenham sido amplamente publicados e lidos pelo público oitocentista, acabaram sendo transformados num escuso verbete de enciclopédia ou até mesmo deixaram de figurar no cânone literário.

2 A referência à gravura de Roubaud e as relações com a produção literária romântica francesa foi explorada em ALLEN, James Smith. Popular French Romanticism. Authors, Readers, and Books in the 19th Century. Syracuse: Syracuse University Press, 1981, p.1-8.

3 Veja: SAINT-BEAUVE. De la littérature industrielle. Revue des Deux Mondes, Paris, v.XIX, p.675-691, julho-setembro de 1839. 


\section{Um herói, uma lenda e muitos mistérios}

No mesmo ano que Roubaud divulgava a sua gravura, o escritor Eugène Sue publicava o romance Les mystéres de Paris nas páginas do periódico de orientação conservadora, Journal des Débats. Sob a forma de capítulos sucessivos publicados no rodapé do jornal, o romance se integrava na recente tradição do gênero folhetim da qual o próprio Sue já havia participado no período de 1839-40 com diversos títulos, como por exemplo, Jean Cavalier, Les Flibustiers, Le Commandeur de Malte, Les aventures d'Hercule Hardi, Le Colonel de Surville.

A publicação dos Mystères teve início no dia 19 de junho de 1842, diagramado em quatro colunas no rodapé da primeira e segunda página do jornal e apresentou o seguinte ritmo e duração: $1^{\text {a }}$ parte: 23 capítulos (19/06 a 13/07), 2a parte: 17 capítulos (06 a 28/09), 3a parte: 14 capítulos (01 a 17/11), 4a parte: 26 capítulos (23/11 a 30/12), 5a parte: 16 capítulos (01 a 19/02), 6a parte: 11 capítulos (16 a 31/03), 7a parte: 30 capítulos (10/05 a 24/06), 8a parte: 21 capítulos (27/07 a 02/09), 8a parte: Epílogo / 8 capítulos $\left(05\right.$ a 15/10) ${ }^{4}$

A crer nos comentaristas do romance, esta data marcou o nascimento de um mito, a do herói-providência, Rodolfo, príncipe de Gerolstein, protagonista principal pelos subterrâneos de Paris. A narrativa convidava os seus leitores a explorar um mundo terrível e desconhecido pela maioria dos assinantes do jornal, constituído por membros dos setores médios e das classes proprietárias. O realismo vívido empregado na representação das cenas de privação enfrentada pelas classes populares é significativamente contrastante com as românticas narrativas melodramáticas utilizadas por Sue nos romances-marítimos que inclusive lhe proporcionaram o título de membro da Legião de Honra em 1839.

As desventuras do Príncipe Rodolfo de Gerolstein, cuja benevolência inata o levara a se arriscar pelos subterrâneos da cidade para retificar as injustiças sociais e reparar erros cometidos contra inocentes, constituem o fio da trama. Vale sublinhar que a princípio, a identidade do personagem não é revelada, assim como a sua condição social era dissimulada pelos trajes que o aproximava dos homens ordinários que circulavam pela Citté e pelo emprego da gíria (argot) das classes populares. ${ }^{5}$

4 Cf. Publication des Mystères de Paris en feuilleton dans le Journal des Debats. In: GALVAN, Jean Pierre. Les Mystères de Paris: Eugène Sue et ses lecteurs. Paris: L'Harmattan, 1998, v.2, p.419-424.

5 O sítio francês www.languefrancaise.net indica a existência de dois dicionários distintos de argot que remetem diretamente à obra de Sue. O primeiro deles é o Dictionnaire de l'argot moderne; ouvrage indispensable pour l'intelligence des Mystères de Paris, de M. Eugène Sue; suivi d'un aperçu physiologique sur les prisons de Paris, etc. Imprimé par Worms à Montmartre, et se vend à Paris, chez Gazel. Sans date [1843]; 1 vol. in-12 de 48 pp.. Já, o segundo dicionário localizado é o Dictionnaire complet de l'Argot employé dans les Mystères de Paris. Ouvrage éminemment utile utile à toute personne honnête puisqu'il divulgue à la société les mots dont les filous, voleurs, floueurs, chevaliers d'industrie composent leur conversation. Ouvrage recueilli par M. D. D'après les renseignements donnés par un ex-surveillant de la Roquette et un ancien garde-chiourme du bagne de Brest. Augmenté de la manière dont la pègre maquille son truque pour poissencher les pantres, les voleurs s'y prennent pour voler les 
Um indicador do retumbante sucesso do romance pode ser apreciado pela elevação das vendas do Journal des Débats ainda quando da publicação do romance sob a forma de folhetim. Com uma subscrição anual de 80 francos, o jornal passou do patamar de 3.600 para cerca de 25.000 exemplares vendidos no espaço de um mês, chegando a registrar a cifra de 40.000 exemplares. A capacidade de alavancar a vendagem do jornal por meio da publicação do romance, que inclusive dispensava o desembolso com o custo da tradução, também foi prontamente adotado pelos proprietários de distintos órgãos da imprensa belga. Desta maneira, informa René Guisse, Les mystères de Paris foi publicado quase que simultaneamente pelo L'Independant, L'Echo de Bruxelles e ainda pelo Le Globe. ${ }^{6}$

Aliás, a repercussão obtida pelo romance permite compreender as alterações introduzidas no Journal des Débats, como por exemplo, a progressiva presença na quarta página de anúncios publicitários. Mas, sobretudo, a mudança no perfil dos assinantes formado por leitores elitistas que se voltavam para os artigos da página de rosto cuja temática geralmente abordava as novidades do mundo diplomático ou dos fatos políticos, econômicos e sociais. Ao longo da publicação dos Mistérios verificou-se a existência de novos leitores que não abonavam o jornal em função de um engajamento político, mas única e exclusivamente para ter acesso ao folhetim. Mesmo considerando-se que o valor da subscrição anual de 80 francos representava um valor ainda muito alto frente aos salários das classes trabalhadoras na França, Jean-Pierre Galvan encontrou algumas cartas que indicam a prática de mear este valor entre membros de um mesmo círculo. ${ }^{7}$

Durante a publicação do romance sob a forma de folhetim, o editor francês Charles Gosselin que já havia publicado diversos títulos de Sue, lançou uma edição ilustrada em 10 volumes "por entrega", revista e corrigida pelo próprio autor. O seu faro editorial não estava equivocado, pois a vendagem demandou sucessivas edições, de maneira que no ano de 1884 ele anunciava o lançamento da sétima edição.

O sucesso do romance rapidamente se espraiou para várias partes da Europa. Entre 1842 e 1843 não menos que três edições foram publicadas em Bruxelas, e em 1845 o editor belga Paulin lançou uma publicação em 10 volumes com o preço de apenas 1 franco por volume. Segundo Anne-Marie Thiesse, a publicação do romance na forma livro também obteve um imenso sucesso, vendendo cerca de 60.000 cópias entre 1842 e $1844 .^{8}$

honnêtes gens. Paris, chez tous les libraires. Sans date [1844]; 1 vol. in-32 de 3 ff. n. chiff. (faux-titre, titre, nouveau faux-titre) et $121 \mathrm{pp}$. Por sua vez, o Projeto Gutenberg disponibiliza o segundo dicionário, veja: www.gutenberg. org/etext24867 Acesso em 23/09/2008.

6 GUISE, René. La diffusion du roman français du XIX`e siècle dans le monde. Le cas des "Mystères de Paris". L'année balzacienne, Paris, n.14, p.407, 1993.

7 GALVAN, J.P. Les Mystères de Paris: Eugène Sue et ses lecteurs.

8 THIESSE, Anne-Marie. Le roman populaire. In: MARTIN, H-J. et CHARTIER, R. (orgs.) Histoire de I'édition française. Paris: Fayard/Cercle de La Librairie, 1985, v.3, p.513. 
De acordo com Pierre Orecchioni, o sucesso dos Mistérios fez surgir um anedotário que contribuiu para a fundação e consolidação de uma legenda em torno do romance. Ele recolheu registros de testemunhos contemporâneos à publicação dos Mistérios que divulgavam com certa freqüência a formação de filas de leitores diante das portas do Journal des Dèbats na madrugada para conseguir um exemplar do número seguinte, de brigas pelo acesso aos exemplares do romance no interior dos gabinetes em função da diminuição do tempo de leitura permitido aos subscritores ou, modulando de uma perspectiva cômica para um tom macabro, como o caso da operária que invadiu a residência do escritor e se enforcou na sala, onde deixou um bilhete no qual informava que a sua atitude limite estava diretamente ligada à penúria e ao fato de Sue ter sido a única pessoa que havia se compadecido e compreendido a alma da gente pobre. ${ }^{9}$

A recepção do romance também pode ser acompanhada pelas intervenções ou respostas dos leitores que, vez ou outra, anotavam suas impressões de leitura em cadernos e diários, mas que também enviavam ao escritor sob a forma de correspondência. Foi com base num corpus documental composto por 400 cartas dirigidas a Eugene Sue por leitores ordinários de diferentes lugares da França e de outros pontos da Europa, que Jean-Pierre Galvan compôs a obra Les Mystères de Paris. Eugène Sue et sés lecteurs. Ao longo desta alentada obra, acompanhamos as reações dos leitores frente ao desenvolvimento da trama, identificando-se com os personagens, sugerindo o desenvolvimento da narrativa, propondo derivações e supressões, etc. Judith Lyon-Caen em La lecture et la vie também procurou compreender por meio da leitura da correspondência de leitores para Sue, os sofrimentos e frustrações que levaram-na a conceber Les Mystères como um romance de atualidade sobre as questões sociais. ${ }^{10}$

Não parece nada fora de propósito registrar que um dos leitores dos Mistérios, quando de sua publicação sob a forma de folhetim, foi Karl Marx que vivia exilado em Paris naquele tempo. A leitura atenta do romance gerou uma série de anotações que tomaram parte do seu livro A Sagrada Família, publicado em 1845. No texto, Marx procurou refutar a tese defendida por Sue, de que a ignorância impedia os ricos de ajudarem os pobres e punha em dúvida a veracidade do socialismo do escritor. ${ }^{11}$

9 ORECCHIONI, P. Eugene Sue. Mesure d'un success. Europe, Paris, n.643-644, p.161-165, 1982.

10 LYON-CAEN, Judith. La lecture et la vie. Les usages du roman au temps de Balzac. Paris: Tallandier, 2006.

11 Veja: LOGE, Celso José. A lanterna mágica do remorso e do prazer: Karl Marx, leitor de Os Mistérios de Paris, de Eugene Sue. São Paulo: FFLCH-USP, 1988 (Sociologia, Tese de doutorado). A discussão sobre o suposto socialismo do autor aparece em BORY, Jean-Louis. Eugène Sue, le roi du roman populaire. Paris: Hachette, 1962; e também em PRENDERGAST, Christopher. For the people, by the people? Eugene Sue's Les Mystères de Paris: A Hypothesis in the Sociology of Literature. Oxford: Legenda, 2003. Para um confronto entre as posições de Eugène Sue e Karl Marx, veja: ACTON, H.B. The illusion of the epoch: Marxism-Leninism as a Philosophical Creed. Indianapolis: Liberty Fund, 2003. 
Barry P. Chevasco optou por seguir outro caminho para compreender aquilo que ele alcunhou de "misteriomania". ${ }^{12}$ Segundo o pesquisador britânico, dificilmente entre os anos 1842 e 1850, alguém na Inglaterra e nos Estados Unidos, independente da sua posição social, não teria ao menos ouvido falar de Eugène Sue, quando não tivesse lido alguma obra dele. Ele sublinha que até o ano de 1844 seis edições traduzidas do romance estavam disponíveis no mercado britânico. A fama do escritor francês só não era ofuscada por Charles Dickens. A sua celebridade estava diretamente ligada à ascensão de novos leitores, do surgimento de um novo e ampliado mercado para os artefatos textuais onde as revistas e jornais passaram a ter um papel importante na divulgação de textos e resenhas sobre os livros recém-lançados. Chevasco procurou acompanhar a recepção de Sue no contexto britânico a partir de dois eixos, a saber: por meio das respostas dos leitores/escritores que procuraram adaptar o romance para a linguagem dramática e daí a presença nos palcos ingleses de diversas montagens que remetiam aos Mistérios de Paris. A outra veia explorada pelo autor foi o paralelo entre o romance de Sue e as classes populares na França, por um lado, e as relações entre o "peny novel" The mysteries of London (1844), de G.W.M. Reynolds, e a cultura da classe trabalhadora na Inglaterra.

O sucesso do romance de Sue na Bélgica, pátria da contrafação na primeira metade do século dezenove, também foi retumbante e não só suscitou diversas edições por parte dos editores ali estabelecidos (Jamar, Haumann, Méline et Cans, Lebéque et Sacré fils), como gerou um intenso debate nas colunas da imprensa local. De acordo com Gustave Charlier, Les Mystères de Paris foi alvo de críticas severas de grupos católicos que apesar de valorizarem as idéias filantrópicas acerca da regeneração dos pobres, denunciavam o mau-gosto da linguagem e, sobretudo, o tom horrível e macabro das ações e de muitos personagens. Já para muitos liberais, os "quadros licenciosos" e "as imagens revoltantes desta obra imoral e perigosa" punham em pauta a questão dos abusos sociais, fato que era reconhecido por eminentes membros da magistratura e deputados belgas. ${ }^{13}$

O rastreamento das traduções reforça o imenso sucesso editorial obtido pelo romance de Sue. Neste caso, o trabalho feito por estes mediadores, na maioria das vezes anônimos, teve um papel fundamental na difusão da obra, disponibilizando o texto para uma heterogênea comunidade de leitores com outra identidade lingüística. Os dados oriundos dos catálogos de diversas bibliotecas ${ }^{14}$ permitiram a elaboração do quadro abaixo.

12 CHEVASCO, Barry P. Mysteriomania. The reception of Eugène Sue in Britain, 1838-1860. Bern: Peter Lang, 2003.

13 CHARLIER, Gustave. Le mouvement romantique en Belgique (1815-1850). Bruxelles: Palais des Academies, 1959, v.ll (Vers un romantisme national), p.421-429.

14 O levantamento de dados se realizou nas Bibliotecas Nacionais de Portugal e França, na Real Biblioteca da Bélgica, na Staatsbibliotheke (Berlim) e na New York Public Library. Acrescente-se a consulta on-line dos catálogos 
Quadro I

Mistérios de Paris - Distribuição por línguas, n. de traduções e local da edição

\begin{tabular}{|l|c|l|}
\hline \multicolumn{1}{|c|}{ Língua } & No traduções & \multicolumn{1}{c|}{ Local } \\
\hline Inglês & 17 & Londres (8); New York (5); Boston (3); Paris (1) \\
\hline Espanhol & 10 & Madri (4); Paris (2); México (2); Barcelona (1), Valência (1) \\
\hline Italiano & 10 & Milão (5); Florença (2); Nápoles (2); Capolago (1) \\
\hline Alemão & 7 & Berlim (2); Leipzig (2); Brün (1); Colônia (1); Stutgard (1) \\
\hline Português & 6 & Lisboa (2); Porto (2); Rio de Janeiro (1); São Luís (1) \\
\hline Catalão & 3 & Barcelona \\
\hline Dinamarquês & 2 & Copenhagen \\
\hline Holandês & 2 & Bruxelas (1); Amsterdam (1) \\
\hline Russo & 2 & S.Petersburgo (1), Moscou (1) \\
\hline Sueco & 2 & Estocolmo \\
\hline Árabe & 1 & Tunis \\
\hline Armênio & 1 & Zwiwnia \\
\hline Grego & 1 & Smirna \\
\hline Hebraico & 1 & Wilna \\
\hline Húngaro & 1 & Pest \\
\hline Idische & 1 & New York \\
\hline Ladino & 1 & Constantinopla \\
\hline Polonês & 1 & Varsóvia \\
\hline Tcheco & Praga \\
\hline
\end{tabular}

O quadro demonstra que a circulação do romance não se restringiu por toute la France, o que não era pouca coisa, mas ganhou paragens diversas e me pareceu significativo para compreender as intersecções entre a literatura e a geografia. Este lugar é o espaço histórico, o terreno concreto onde atuam comunidades heterogêneas formadas por leitores, livreiros, editores, impressores e uma vasta gama de intermediários culturais. As disputas pelos mercados levaram muitos dos sujeitos envolvidos 
na produção e distribuição dos artefatos textuais adotarem estratégias comerciais que visavam atingir os leitores e auferirem lucro na operação. Desta forma o quadro ilustra o aparecimento de filiais de empresas voltadas para a edição de livros em língua estrangeira (é o caso da edição francesa em língua espanhola e inglesa), indica a existência de diferentes traduções produzidas por países de mesma identidade lingüística (traduções portuguesas e brasileiras, britânicas e americanas, espanholas e mexicanas, belgas e holandesas), explicita fraturas internas nas unidades territoriais e políticas (traduções espanholas em catalão e castelhano) e, por fim, ilumina a existência de projetos editoriais que transcendem as fronteiras do Estadonação (edição americana em ídische voltada para a comunidade judaica ashkenazi, edição turca em ladino para a comunidade judaica sefardita, edição tunisiana para a comunidade árabe, edição lituana em hebraico para a comunidade judaica).

Se a quantidade de edições e traduções revelou-se surpreendente, causou-me ainda maior espécie perceber que alguns catálogos indicavam modalidades mais complexas e matizadas de recepção do romance de Eugène Sue. Naqueles casos onde a rigidez das rubricas empregadas para ordenar as classes do conhecimento deu lugar ao mero arrolamento das obras sob o padrão alfabético me permitiu vislumbrar a existência de vários romances que apelavam para um título muito próximo ao dos Mistérios de Paris.

Mais uma vez, a atenção para determinadas regularidades produzidas pela acumulação de registros, indicava que o romance não fora apenas objeto de fruição de leitores que buscavam consolo para as suas mazelas. A fórmula "Mistérios de ..." foi apropriada por alguns leitores que logo perceberam as potencialidades deste modelo narrativo para engendrar outros romances. Portanto, não parece equivocado afirmar que um efeito não previsto na leitura do romance de Sue foi despertar a inventividade de alguns homens que se valeram deste modelo narrativo para testar a sua capacidade de se apresentarem como escritores. Mas não só. O vigor e o sucesso obtidos com os Mistérios também foram perseguidos por outros tantos escritores já consagrados naquele momento, tais como Alexandre Dumas, Xavier de Montépin, Camilo Castello Branco, Émile Zola, entre outros.

As razões para estes gestos que apelavam para a imitação e o empréstimo de modelos narrativos devem ter as mais diversas explicações. Entretanto, devo reconhecer que ainda não tenho respostas que consigam suplantar uma asserção bastante óbvia e que repousa no fato de que todo escritor almeja o reconhecimento e ainda mais se existir a possibilidade de fazer fortuna com a própria pena.

Para além desta hipótese mais óbvia, me parece que o modelo empregado por Sue foi amplamente positivo para inquirições acerca do cenário 
urbano e do cotidiano de seus habitantes, com especial deferência às misérias e a opressão da gente humilde. Ainda que correndo algum risco por me limitar à abonação dos títulos das obras, ${ }^{15}$ acredito que os Mistérios deflagraram outro tipo de resposta por parte dos escritores oitocentistas que incidiu na ficcionalização do espaço.

A operação de examinar, ler e recolher sinalizadores espaciais presentes nos títulos e subtítulos dos romances arrolados nos catálogos favoreceu a construção do quadro abaixo. Ele tem o mérito de permitir traçar um mapamundi imaginário da geografia literária instituída pelos leitores de Eugène Sue e os efeitos da concretização daquela leitura sobre os novos romances formatados no modelo Mistérios de ....

\section{Quadro II}

“Mistérios de...”: Países, cidades, paisagens e monumentos no século XIX

\section{EUROPA}

\begin{tabular}{|l|l|}
\hline \multirow{3}{*}{ França } & $\begin{array}{l}\text { Sena (1844), Paris (1845), Rouen (1845), Nancy (1845), Paris (1846), } \\
\text { Santa Helena (1847), Tulherias (1848), Lyon (1852), Paris (1854), Lyon } \\
\text { (1856), Saint Bartelemy (1860), Louvre (1860), Paris (1865), Palais Royal } \\
\text { (1865), Paris (1866), Havre (1868), Marselha (1870), Provence (1872), } \\
\text { Boulevard dos Inválidos (1874), Lille (1875), Royan (1876), Bastilha } \\
\text { (1878); Marselha (1879), Nice (1883). }\end{array}$ \\
\hline Portugal & $\begin{array}{l}\text { Lisboa (1851), Lisboa (1854), Porto (1857), Coimbra (1861), Alente- } \\
\text { jo (1871), Aldeia (1873), Ponta Delgada (1874), Fafe (1877), Lisboa } \\
\text { (1879), Funchal (1881), Porto (1890), Alfama (1897). }\end{array}$ \\
\hline Espanha & $\begin{array}{l}\text { Barcelona (1844), Madri (1844), Madri (1844-45), Madri (1845), Cádiz } \\
\text { (1845), Barcelona (1862), Madri (1863), Madri (1863), Palma de Major- } \\
\text { ca (1866), Escorial (1869), Madri (1873). }\end{array}$ \\
\hline Itália & $\begin{array}{l}\text { Roma (1847), Roma (1854), Trieste (1853), Nápoles (1856), Milão } \\
\text { (1857), Trieste (1858), Nápoles (1863), Milão (1867), Veneza (1881), } \\
\text { Roma (1887). }\end{array}$ \\
\hline Inglaterra & $\begin{array}{l}\text { Londres (1844), Londres (1844), Londres (1844), Londres (1844); Lon- } \\
\text { dres (1844), Manchester (1844), Londres (1849), Londres (1850). }\end{array}$ \\
\hline Rússia & $\begin{array}{l}\text { Rússia (1845), Palácio do Czar (1870), S. Petersburgo (1877), Rússia } \\
\text { (1882), Kremlin (1896). }\end{array}$ \\
\hline Alemanha & Berlim (1845), Hamburgo (1855), Wiesbaden (1862), Berlim (1871). \\
\hline Mônaco & Mônaco (1884), Mônaco (1885), Mônaco (1888). \\
\hline Polônia & Varsóvia (1845), Varsóvia (1847), Cracóvia (1888). \\
\hline
\end{tabular}

15 A interpretação dos romances publicados no Brasil e Portugal faz parte do presente projeto de investigação. Todavia, para efeito desta publicação, este tópico não foi incorporado. 


\begin{tabular}{|l|l|}
\hline Turquia & Constantinopla (1862), Constantinopla (1891), Constantinopla (1897). \\
\hline Áustria & Viena (1844), Viena (1852). \\
\hline Hungria & Pest (1853), Schachtizburg (1854). \\
\hline Bélgica & Bruxelas (1849). \\
\hline Bulgária & Bulgária (1876). \\
\hline Rep. Tcheca & Praga (1875). \\
\hline
\end{tabular}

\section{AMÉRICA}

\begin{tabular}{|l|l|}
\hline \multirow{2}{*}{ Brasil } & $\begin{array}{l}\text { Morro de S. Teresa (s/d), Brazil (1845), Rio de Janeiro (1854), Brasil } \\
\text { (1855), Bahia (1860), Roça (1861), Rio de Janeiro (1874), Rio de Janei- } \\
\text { ro (1874), Recife (1875), Rio de Janeiro (1880), Rio de Janeiro (1881), } \\
\text { Tijuca (1882), Botucatu (1884). }\end{array}$ \\
\hline EUA & $\begin{array}{l}\text { Fichburg (1844), Boston (1844), New York (1847), New York (1848), } \\
\text { Saint Louis (1851), New Orleans (1851), EUA (1853), Philadelphia } \\
\text { (1853), New York (1863), New York (1874), Chicago (1889). }\end{array}$ \\
\hline Argentina & Plata (1852), San José (1866), Argentina (1866). \\
\hline Canadá & Montreal (1881), Montreal (1894), Montreal (1898). \\
\hline México & México (1850). \\
\hline Venezuela & Mérida (1846), Santa Cruz (1864). \\
\hline Guiana & Guiana (1892), \\
\hline
\end{tabular}

ÁSIA

\begin{tabular}{|l|l|}
\hline China & China (1860), Pequim (1883). \\
\hline Filipinas & Filipinas (1859) \\
\hline & Povo árabe (1860) \\
\hline Índia & Índia (1868) \\
\hline
\end{tabular}

\section{OCEANIA}

\begin{tabular}{|l|l|}
\hline Austrália & Melbourne (1891) \\
\hline
\end{tabular}

O quadro evidencia a difusão e, sobretudo, a potencial apropriação do modelo ficcional formulado por Eugène Sue numa impressionante escala mundial. O que reforça o argumento de alguns investigadores que atribuem aos Mistérios o fato de ser um dos primeiros best-sellers da era da ficção industrial. Pelo que se viu até aqui, a fórmula "Mistérios de ..." funcionou 
como um modelo narrativo empregado por escritores já consagrados nos seus respectivos sistemas literários, mas também forneceu distinção ou uma fugaz notoriedade para aqueles desconhecidos que almejavam uma posição na carreira das letras. Como se isto não bastasse, vale sublinhar que estas variantes e derivações foram publicadas na forma de rodapé do jornal (folhetim) e de livro, isto é, foram mercadorias que alimentaram o circuito de produção, distribuição e consumo de bens da cultura letrada. Neste caso, como em qualquer negócio, a publicação dos livros constituiuse numa operação de risco, gerando assim lucro ou prejuízo para aqueles intermediários responsáveis pela transformação do manuscrito em livro. Aos olhos dos leitores, a disponibilidade de tantos "Mistérios de ..." pode ter funcionado como um passaporte para viagens imaginárias por países, cidades e paisagens.

\section{Os Mistérios de Paris no Brasil: formas de circulação e modos de edição}

Não é difícil constatar que o romance de Sue circulou nestas terras sob diversos padrões editoriais. Foi Marlyse Meyer quem primeiro reconstituiu o desembarque dos Mistérios no cais Pharoux e a sua difusão entre o público do Rio de Janeiro, por meio de uma leitura atenta dos anúncios na imprensa fluminense. Tudo indica que as primeiras formas de circulação tenham sido sob a modalidade livro, antes mesmo da conclusão da série no rodapé do Journal des Débats, conforme se pode apreender na nota inserida no Jornal do Commercio, na data de 26 de setembro de 1843: "Quem tiver a obra Mystères de Paris, por Eugene Sue, e quiser vendê-la, dirija-se à rua do Ouvidor, 87, loja de Mongie". ${ }^{16}$

Alguns meses mais tarde, em 29 de janeiro de 1844, um novo anúncio informava a chegada dos dois últimos volumes da série, indicando se tratar de uma edição por entregas ("livraison"), para o deleite dos subscritores do gabinete de leitura de Mlle. Edet. ${ }^{17}$ Outros comerciantes radicados na corte imperial também arrolaram os Mistérios entre as novidades livrescas recém desembarcadas, como foi o caso de Mongie, proprietário de um gabinete de leitura instalado na rua do Ouvidor $n^{\circ} 87$, que informava:

Prévient MM. les abonnés qu'ill vient recevoir par le Génie: Le comte de Gérolstein, par Sue; (...) Mongie continuera à recevoir les ouvrages nouveaux avec une telle

16 Apud: MEYER, Marlyse. Folhetim: uma história. São Paulo: Companhia das Letras, 1996, p.281. "Misteriomania" é um projeto tributário deste e de outros trabalhos precursores de Marlyse Meyer.

17 "Mlle. Edet prévient messieurs les abonnés de son cabinet de lecture qu'elle vient de recevoir par le navire 'Le Gênie' la neuvième et dernière partie des 'Mystères de Paris', y compris 'Gerolstein', par m. Eugene Sue". In: Jornal do Commercio (RJ), 29/01/1844. Apud: MEYER, Marlyse. Folhetim: uma história, p.281. 
exactitude, que MM. ses abonnés pourrant les lire deux mois apres leur publication à Paris: prix de l'abonnement $2 \$$ par mois. ${ }^{18}$

Os anúncios são bastante enfáticos em demonstrar o grau de atualização e a sagacidade dos comerciantes franceses estabelecidos na cidade do Rio de Janeiro em fornir os seus gabinetes de leitura e livrarias com as mais recentes produções do mercado editorial francês. A menção ao tempo necessário para os subscritores terem acesso aos impressos estrangeiros era uma inequívoca jogada autopromocional dos donos dos estabelecimentos devotados ao aluguel e comércio de livros e, de quebra, servia para justificar o preço da assinatura. No entanto, é curioso constatar que o título da obra anunciada aparece corrompido com a menção do nome do principal protagonista no lugar da referência à ambientação da narrativa.

Somente depois de circulação do livro é que o público fluminense e quiçá brasileiro passou a ter acesso a forma do folhetim, publicado nas páginas do Jornal do Commercio (RJ), no período de 01 de setembro de 1844 a 20 de janeiro de 1845. Isto significou, entre outras coisas, a adoção de um padrão tipográfico semelhante: texto inicialmente diagramado em quatro colunas no rodapé das duas primeiras páginas do jornal, o gradativo emprego do rodapé da terceira página, a introdução de suplementos (especialmente aos domingos) e a diminuição do tamanho dos tipos para acelerar o ritmo da publicação. ${ }^{19}$

A publicação dos Mistérios parece ter recebido uma acolhida muito positiva entre o público carioca, obrigando o tradutor adotar uma velocidade que atendesse a receptividade dos leitores. O amigo Salvador de Mendonça relata o ritmo frenético de trabalho de José Justiniano da Rocha, espremido entre as necessidades de produzir de acordo com o compromisso firmado com o dono do jornal e as pressões dos leitores para obter informações sobre o desenvolvimento da trama pelos subterrâneos da longínqua Paris.

Se o não tivesse eu visto trabalhar dificilmente acreditaria que dentro de um só mês pudesse encaixar a tradução de três volumes dos Mistérios de Paris ou de dois e meio do Conde de Monte Cristo. Mas vendo-o na sua comprida varanda a ditar sucessivamente a dois escreventes, colocados nos extremos do com-

18 Jornal do Commercio (RJ), 05/02/1844 n.35, p.4. No dia 18/08/1844, um anúncio publicado no mesmo jornal informava a venda do romance em francês editado em 10 volumes, no Gabinete de leitura de Mlle. Edet. In: Jornal do Commercio (18/08/1844), n.217, p.3.

19 A aproximação do fim da trama associada à exigüidade de matérias a serem noticiados em função do calendário das festas de fim de ano parecem ter contribuído para a publicação de suplementos e o aumento da quantidade de texto do romance publicada no jornal. Veja, por exemplo: a edição do dia 24/12/1844 foi acompanhada de um suplemento (n.342) com 2 páginas, exclusivamente com o texto dos Mistérios. A edição natalina do Jornal do Commercio trazia o romance nas páginas 1 e 2, bem como, quase a totalidade da página 3. A mesma quantidade de texto foi editada na edição do dia 26/12/1842. Finalmente, no dia 31/12/1844, o jornal oferecia um suplemento (n.349) de duas páginas aos seus leitores, sendo que uma delas era integralmente dedicada aos Mistérios e, na seguinte, o texto de Sue ocupava cerca três colunas e meia. 
partimento, ora do capítulo da mão esquerda, ora do capítulo da mão direita, com o só intervalo do passeio de uma à outra mesa, compreendi a vantagem do sistema, que já pus também em prática e recomendo aos que tiverem de ditar traduções com pressa. ${ }^{20}$

Nada posso dizer sobre a fidelidade ou não da tradução, da capacidade de adaptação ou condensação empregada pelo letrado brasileiro. Todavia, o texto encontra-se eivado de notas-de-rodapé, tal qual a publicação original, cuja função é a de esclarecer para o leitor o léxico cifrado dos bandidos, criminosos e da gente ordinária que circula no espaço romanesco: o "argot".

O esforço de Justiniano José da Rocha teve amparo por parte dos leitores e tudo leva a crer que a publicação do romance deve ter alavancado a vendagem do jornal. De acordo com as práticas comerciais empregadas pelos proprietários de empresas jornalísticas, o sucesso de um folhetim era acompanhado pela publicação da obra na forma livro, para auferir ganhos por meio da venda para leitores interessados na repercussão do livro e, de quebra, fazer propaganda do jornal.

É assim que cerca de um mês após o início da publicação do romance no rodapé do jornal, era divulgado um reclame com letras garrafais que tomava a largura integral da página, com a seguinte informação: "ACHAM-se à venda em casa de J.Villeneuve \& Cia., rua do Ouvidor n. ${ }^{\circ} 65$, OS MYSTÉRIOS DE PARIS. Primeira Parte - 1 vol. - nítida edição - $1 \$ 000$ rs". E mais abaixo, com letras miúdas "impresso no prelo mechanico da Typographia Imperial e Constitucional de J. Villeneuve e Comp.". ${ }^{21}$

Ao cotejar o rodapé do jornal e a seção de anúncios foi possível identificar dois movimentos que apesar de distintos, convergem no sentido de permitir a compreensão das estratégias de divulgação e comercialização do romance. A primeira delas diz respeito ao lançamento sucessivo dos volumes do romance sob a forma livro à medida que a narrativa dos Mistérios avançava nas tiras do jornal. O quadro abaixo ilustra este movimento

20 MENDONÇA, Salvador de. Cousas de meu tempo. Revista do Livro, Rio de Janeiro, n.20, v.5, 1960. René Guise ao comentar a difusão do romance francês oitocentista, com especial atenção para os Mistérios de Paris, menciona esta edição do Jornal de Commercio. Ele agrega uma informação atribuída a uma estudante brasileira cujo trabalho se debruçou sobre a tradução do romance e conclui que "ce travail était I'oeuvre de deux traducteurs qui se relayaient: I'um était Français d'origine, et sa traduction dont le portugais n'est pas toujours correct, ne comporte pás de contresens sur le texte français; I'autre était Brésilien: son portugais est excellent, mais Le texte français n'a pas toujours été bien compris". GUISE, René. La diffusion du roman français du XIXe siècle dans le monde. Le cas des "Mystères de Paris", p.410. Lamentavelmente, o texto não fornece indicação alguma sobre o trabalho da tradução.

21 Jornal do Commercio (RJ), 29/09/1844, n.258, p.4. 


\section{Quadro III}

Evolução da publicação dos Mistérios de Paris no jornal e livro

\begin{tabular}{|c|c|c|}
\hline Anúncio & Livro & Jornal \\
\hline 29/09/1844, n² 258, p.4 & $1^{\circ}$ volume & $2^{\text {a }}$ Parte - V. Uma casa na rua do Templo \\
\hline $18 / 10 / 1844, n^{\circ} 277$, p.3 & $2^{\circ}$ volume & $4^{\text {a }}$ Parte - I. Clemência d' Harville \\
\hline 03/11/1844, n 292, p.4 & $3^{\circ}$ volume & $4^{\text {a }}$ Parte $-X V$. A descoberta \\
\hline 26/11/1844, n 315, p.4 & $4^{\circ}$ volume & $5^{\text {a }}$ Parte - X. A loba e a Gueladeira \\
\hline 13/12/1844, n 331, p.4 & $5^{\circ}$ volume & $\begin{array}{l}6^{\text {a }} \text { Parte }-\mathrm{VI} \text { - As victimas de um abuso de } \\
\text { confiança }\end{array}$ \\
\hline 27/12/1844, n 345, p.4 & $6^{\circ}$ volume & 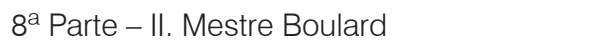 \\
\hline 04/01/1845, n 4, p.3 & $7^{\circ}$ volume & 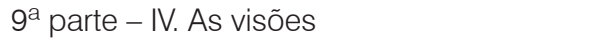 \\
\hline 01/02/1845, n 31, p.4 & $8^{\circ}$ volume & Publicação encerrada \\
\hline 05/02/1845, n 35, p.4 & $\begin{array}{l}9^{\circ} \text { e } 10^{\circ} \\
\text { volumes }\end{array}$ & Publicação encerrada \\
\hline
\end{tabular}

Como se vê, a publicação do romance seguia ritmos distintos de acordo com o produto final. Os anúncios veiculados pela Casa Villeneuve reforçam a percepção de que não havia concorrência entre os modos de edição do romance, sobretudo porque o lançamento dos volumes apresentava intervalos irregulares. Acrescente-se ainda que a publicação quase que diária do folhetim garantia uma folga de, ao menos, uma parte do romance, matéria suficiente para compor mais um volume.

Convém sublinhar que este intervalo não só não interferia na evolução da publicação de cada um dos produtos, mas também poderia estimular a aquisição dos livros. Neste sentido, parece ser relevante a inserção do anúncio dos proprietários do Jornal do Commercio publicado cerca de um mês após o lançamento do primeiro volume da série, informando que "Tendo-se esgotado, haverá 10 ou 12 dias, a primeira edição dos Mysterios de Paris, e tendo sido muito procurada ultimamente esta obra, participa-se ao publico que se está imprimindo a segunda edição, que ficará pronta na semana que vem. SAIRÃO á luz em casa de J.Villeneuve \& Cia., rua do Ouvidor, 65". ${ }^{22}$

Já o segundo movimento possível de ser apreendido nas páginas da imprensa fluminense diz respeito às estratégias comerciais empregadas pelos livreiros e proprietários de gabinetes de leitura no sentido de auferir 
lucro com a "febre de leitura" suscitada pelos Mistérios. A disputa pelos potenciais compradores e/ou assinantes se traduzia no oferecimento de edições de diferentes formatos, número de volumes ou com a presença de ilustrações. É o que atestam, por exemplo, alguns reclames reproduzidos abaixo:

A vendre, rue d'Ouvidor 65, Les Mystères de Paris, 10 vol. in- $4^{\circ}$ reliès. Prix $40 \$ 000$ (JC 11/09/1844 n²99 p.4) Casa Villeneuve

Les Mystères de Paris, par Eugene Sue, I' ouvrage complet, en français: vende-se na rua do Ouvidor n87, loja de E. Mongie (JC 19/11/1844 n³08 p.4)

Alugão-se livros em francez, portuguez, inglez e hespanhol: na rua da Alfândega $n^{\circ} 135$, novo gabinete de leitura: a mesma assignatura dá direito aos 4 idiomas, cujos catálogos são impressos. Há quatro jogos dos Mysterios de Paris em francez, para mais facilitar a leitura (JC 22/12/1844 n³40 p.2)

Os Mysterios de Paris, em francez, por Eugene Sue, ornado por 500 gravuras pelos melhores artistas de França; preço $15 \$$ réis; vendem-se na livraria BelgoFranceza, rua dos Ourives n75 (JC 05/02/1845 n³5 p.4)

Les Mystères de Paris, por Eugene Sue, 1 grosso volume encadernado; vende-se por $8 \$ 000$ rs., na rua do Ouvidor n 75, loja ingleza (JC 04/04/1845 n88 p.4)

Os anúncios também indicam algumas das dificuldades enfrentadas pelos leitores que não tinham fluência ou capacidade de decifrar o texto na língua original. Longe de adotarem uma reserva de mercado para edição em língua francesa, os comerciantes de livros se deparavam com uma situação bastante objetiva: a da inexistência até aquele momento de uma tradução integral do romance no vernáculo. Basta registrar que a tradução portuguesa levada a cabo por José Pereira dos Reis e editada pela Tipografia da Revista, na cidade do Porto, encontrava-se em andamento. ${ }^{23}$

Tudo leva a crer que a aposta de Villeneuve no potencial de vendas do romance publicado no seu jornal e também da edição em livro preparada pela sua casa tenha sido uma decisão deliberada de alguém que conhecia as artes do fazer tipográfico, além de possuir inequívoco tino comercial e lógica editorial. Para corroborar esta asserção, é importante comparar o custo da assinatura do jornal com a subscrição dos gabinetes de leitura, uma vez que estas instituições ofereciam o acesso ao romance, quer na forma do jornal diário, quer na forma do livro (neste caso apenas na língua original). Considerando-se que o custo da subscrição (abonnement de lecture) dos gabinetes de leitura de Mongie, Désiré-Dujardin e Mlle. Edet era de 2\$000

23 A tradução de José Pereira Reis se estendeu de 1843 a 1846 e foi publicada em 8 volumes in $8^{\circ}$ grande, cf. RODRIGUES, A. A. Gonçalves. A tradução em Portugal (1835-1850). Lisboa: Instituto de Cultura e Língua Portuguesa/ Ministério da Educação, 1992, v.ll. 
réis ao mês, ${ }^{24}$ e que a acessibilidade do material estava limitada ao número de exemplares disponibilizados, fica claro que a opção pela assinatura do Jornal do Commercio era uma forma mais cômoda e quiçá financeiramente mais adequada de conhecer as tramas do Príncipe Rodolfo, Flor-de-Maria, Mestre-Escola, Coruja e dos demais personagens que circulam pelos Mistérios, conforme os dados expostos no quadro abaixo:

\section{Quadro IV}

Assinatura do Jornal do Commercio (RJ)

\begin{tabular}{|c|c|c|}
\hline Preço & Corte & Província \\
\hline Anual & $20 \$ 000$ rs. & $24 \$ 000$ rs. \\
\hline Semestral & $10 \$ 000$ rs. & $13 \$ 000$ rs. \\
\hline Trimestral & $5 \$ 000$ rs. & $7 \$ 000$ rs. \\
\hline
\end{tabular}

Embora não tenha obtido o preço do exemplar avulso do jornal, constata-se que entre setembro de 1844 a meados de janeiro de 1845, um hipotético leitor gastaria $8 \$ 000$ réis para ter acesso ao romance via gabinete de leitura. Esta importância é cerca de $1 \$ 300$ réis mais cara que as diferentes opções pela assinatura do jornal no mesmo período, sem contar que a leitura poderia ser partilhada uma vez que ela não estava circunscrita ao espaço do gabinete.

Para corroborar a asserção acerca da argúcia de Villeneuve e dos ganhos que ele deve ter obtido com a comercialização dos Mistérios, recordo que a legislação fiscal ao longo do século XIX atribuía taxas preferenciais para o papel impresso em detrimento do papel empregado na impressão e encadernação, o que tornava de saída o livro produzido no Brasil mais caro que o similar importado. ${ }^{25}$ Portanto, mesmo sob condições adversas, ele conseguiu oferecer a edição do romance por $1 \$ 000$ réis o volume, perfazendo a importância de $10 \$ 000$ réis pela coleção. Quando comparado com os valores cobrados pelos livreiros estabelecidos na cidade, verifica-se que o preço sugerido por Villeneuve é bastante competitivo, com a vantagem de proporcionar o acesso ao romance para um número maior de leitores, posto que a obra estava traduzida.

Não resta dúvida que a obra de Sue caiu no gosto do público e obrigou o seu editor no Brasil a preparar uma nova edição. Prova disso é o fato de que no mesmo ano que havia sido encerrada a publicação do folhetim e finda a edição em livro era divulgada nas páginas do Jornal do Commercio, no dia 03

24 Os dados relativos ao valor da assinatura dos gabinetes de leitura foram retirados de SCHAPOCHNIK, Nelson. Os jardins das delícias: gabinetes literários, bibliotecas e práticas de leitura no Rio de Janeiro oitocentista. São Paulo: FFLCH-USP, 1999 (História, Tese de doutorado).

25 Os dados sobre a legislação aduaneira são mencionados por HALLEWELL, Laurence. O livro no Brasil: sua história. São Paulo: T.A.Queiroz, 1985, p.150-155. 
de dezembro de 1845: "OS MYSTERIOS DE PARIS em portuguez reimprimirãose e achão-se á venda na rua do Ouvidor n 65". E ainda no mesmo dia, outro anuncio informava a venda do romance em português numa edição em 10 volumes por $8 \$ 000$ rs. ${ }^{26} \mathrm{~A}$ febre de leitura despertada pelo romance parece não ter cedido e alguns meses após o lançamento de uma nova edição, um leitor publica uma nota na seção "À pedidos" com o seguinte teor: "Comprão-se os Mysterios de Paris, em segunda mão, o Judeo Errante e o Monte-Christo, sendo em portuguez; na rua de S. Pedro, 178". ${ }^{27}$ Mas a fortuna editorial dos Mistérios de Paris não se encerrava por aqui, pois de acordo com o arrolamento preparado para o "Catálogo dos livros do Gabinete Português de Leitura do Maranhão" (1867) figurava um exemplar produzido no Rio de Janeiro e datado de 1847, identificado como sendo a sua $4^{a}$ edição!

Aliás, foi também nesta província, tão longe da corte imperial, que foi tirada outra edição dos Mistérios de Paris. A "Atenas brasileira", de acordo com a expressão cunhada por José Veríssimo, foi considerada por Hallewell como a responsável pelos impressos mais bem acabados do império brasileiro, decorrente da existência de equipamentos, de domínio técnico e soluções empreendidas pelos impressores locais. ${ }^{28}$ Apesar de incompleta, esta foi a única coleção impressa no Brasil que consegui localizar ao longo desta investigação. O quadro abaixo indica algumas características desta edição da Typ. de R.A.R. de Araujo e impressa por R.J. de A. Couceiro.

\section{Quadro V}

Edição maranhense de Mysterios de Paris

\begin{tabular}{|c|c|c|c|}
\hline Tomo & Ano de publicação & No páginas & No capítulos \\
\hline I & 1845 & 431 & 24 \\
\hline$I I$ & - & - & - \\
\hline$I I$ & - & - & 28 \\
\hline IV & 1845 & 532 & 17 \\
\hline$V$ & 1846 & 372 & 12 \\
\hline VI & 1846 & 366 & - \\
\hline VII & - & - & - \\
\hline VIII & - & - & 18 \\
\hline$I X$ & 1847 & 383 & 8 \\
\hline$X$ & 1847 & 174 & \\
\hline
\end{tabular}

26 Jornal do Commercio (RJ), 03/12/1845 n.321 p.3 e 4, respectivamente.

27 Jornal do Commercio (RJ), 22/03/1846 n.74 p.4.

28 HALLEWELL, L. O livro no Brasil: sua história, p.102. Note-se que ao comentar o Catálogo da Biblioteca do Gabinete Português de Leitura no Maranhão, publicado por José Maria Corrêa de Frias em 1867, o autor comete um equívoco tremenda ao afirmar que entre as produções locais encontrava-se "uma tradução de Mysterios de Paris, de Eugene Sue, de 1843, dois anos antes da edição do Rio de Janeiro". 
O número de capítulos incorporados em cada volume tende a ser parecido com aquele empregado por Villeneuve. Todavia a ausência dos demais volumes e da edição fluminense impede uma comparação da tradução e análise mais detalhada das demais características destas coleções.

\section{Dos balcões aos catálogos}

Ao saltar dos balcões das livrarias e dos anúncios publicados no Jornal do Commercio (RJ) para investigações em paragens mais distantes, pude consultar, recolher e sistematizar informações publicadas em catálogos de bibliotecas e gabinetes de leitura que foram sendo instituídos em diversos pontos do território brasileiro ao longo do século XIX. Este movimento permitiu ampliar consideravelmente a compreensão da difusão do romance nestas terras.

O quadro seguinte apresenta de maneira organizada os dados colhidos em distintos arquivos e bibliotecas brasileiras.

\section{Quadro VI}

Presença do romance Mistérios de Paris nos catálogos de bibliotecas e gabinetes de leitura brasileiros

\begin{tabular}{|l|l|l|c|c|}
\hline \multicolumn{1}{|c|}{ Instituição e data do catálogo } & Língua & Local & $\begin{array}{c}\text { Ano da } \\
\text { edição }\end{array}$ & Descrição \\
\hline $\begin{array}{l}\text { Bibliotheca Fluminense (Rio de } \\
\text { Janeiro) } \mathbf{1 8 4 8}\end{array}$ & Francês & Paris & 1845 & 5 v. In $18^{\circ}$ \\
\hline $\begin{array}{l}\text { Bibliotheca Fluminense (Rio de } \\
\text { Janeiro) } \mathbf{1 8 4 8}\end{array}$ & Português & $\begin{array}{l}\text { Rio de } \\
\text { Janeiro }\end{array}$ & 1844 & $5 \mathrm{v}$. \\
\hline $\begin{array}{l}\text { Bibliotheca Rio-Grandense (Rio } \\
\text { Grande) } \mathbf{1 8 5 4}\end{array}$ & Português & $\begin{array}{l}\text { Rio de } \\
\text { Janeiro }\end{array}$ & 1845 & $5 \mathrm{v}$. \\
\hline $\begin{array}{l}\text { Gabinete Português de Leitura do } \\
\text { Rio de Janeiro (Rio de Janeiro) } \\
\mathbf{1 8 5 8}\end{array}$ & Português & $\begin{array}{l}\text { Rio de } \\
\text { Janeiro }\end{array}$ & $\mathrm{s} / \mathrm{d}$ & 2 exemplares \\
\hline $\begin{array}{l}\text { Gabinete Português de Leitura de } \\
\text { Pernambuco (Recife) } \mathbf{1 8 5 9}\end{array}$ & Português & Porto & 1843 & $4 \mathrm{v}$. \\
\hline $\begin{array}{l}\text { Gabinete Português de Leitura de } \\
\text { Pernambuco (Recife) } \mathbf{1 8 5 9}\end{array}$ & Português & $\begin{array}{l}\text { Rio de } \\
\text { Janeiro }\end{array}$ & 1847 & $5 \mathrm{v}$. \\
\hline $\begin{array}{l}\text { Gabinete Português de Leitura de } \\
\text { Pernambuco (Recife) } \mathbf{1 8 5 9}\end{array}$ & Português & Lisboa & 1851 & $5 \mathrm{v}$. \\
\hline $\begin{array}{l}\text { British Subscription Library (Rio de } \\
\text { Janeiro) } \mathbf{1 8 6 4}\end{array}$ & Inglês & Londres & - & $3 \mathrm{v}$. \\
\hline $\begin{array}{l}\text { Bibliotheca Fluminense (Rio de } \\
\text { Janeiro) } \mathbf{1 8 6 6}\end{array}$ & Português & $\begin{array}{l}\text { Rio de } \\
\text { Janeiro }\end{array}$ & $1844-45$ \\
\hline
\end{tabular}




\begin{tabular}{|c|c|c|c|c|}
\hline Instituição e data do catálogo & Língua & Local & $\begin{array}{l}\text { Ano da } \\
\text { edição }\end{array}$ & Descrição \\
\hline $\begin{array}{l}\text { Bibliotheca Fluminense (Rio de } \\
\text { Janeiro) } \mathbf{1 8 6 6}\end{array}$ & Francês & Paris & 1845 & $5 \mathrm{v} \cdot \ln 18^{\circ}$ \\
\hline $\begin{array}{l}\text { Bibliotheca Fluminense (Rio de } \\
\text { Janeiro) } \mathbf{1 8 6 6}\end{array}$ & Português & Lisboa & $1845-46$ & $8 \mathrm{v} . \ln 8^{\circ} \mathrm{gr}$ \\
\hline $\begin{array}{l}\text { Bibliotheca Fluminense (Rio de } \\
\text { Janeiro) } \mathbf{1 8 6 6}\end{array}$ & Português & Lisboa & 1848 & $9 v \cdot \ln 16^{\circ}$ \\
\hline $\begin{array}{l}\text { Gabinete Português de Leitura do } \\
\text { Maranhão (São Luís) } 1867\end{array}$ & Português & S.Luis & 1845 & $5 \mathrm{v} \cdot \ln 8^{\circ}$ \\
\hline $\begin{array}{l}\text { Gabinete Português de Leitura do } \\
\text { Maranhão (São Luís) } 1867\end{array}$ & Português & $\begin{array}{l}\text { Rio de } \\
\text { Janeiro }\end{array}$ & 1847 & $\begin{array}{l}5 \text { v. In } 8^{\circ} \\
4^{a} \text { ed. }\end{array}$ \\
\hline $\begin{array}{l}\text { Gabinete Português de Leitura do } \\
\text { Rio de Janeiro (Rio de Janeiro) } \\
\mathbf{1 8 6 8}\end{array}$ & Português & Porto & 1846 & $\begin{array}{c}8 \mathrm{v} \cdot \operatorname{In} 8^{\circ} \mathrm{gr} \\
2 \text { exemplares }\end{array}$ \\
\hline $\begin{array}{l}\text { Gabinete Português de Leitura do } \\
\text { Rio de Janeiro (Rio de Janeiro) } \\
\mathbf{1 8 6 8}\end{array}$ & Português & Lisboa & 1848 & $18 \mathrm{v} \cdot \ln 16^{\circ}$ \\
\hline $\begin{array}{l}\text { Gabinete Português de Leitura do } \\
\text { Rio de Janeiro (Rio de Janeiro) } \\
\mathbf{1 8 6 8}\end{array}$ & Português & Porto & 1864 & $\begin{array}{c}16 \text { v. In } 8^{\circ} \\
\text { Nova edição }\end{array}$ \\
\hline $\begin{array}{l}\text { Gabinete Português de Leitura do } \\
\text { Rio de Janeiro (Rio de Janeiro) } \\
\mathbf{1 8 6 8}\end{array}$ & Português & Lisboa & 1850 & $\begin{array}{l}10 \mathrm{v} . \text { In } 8^{\circ} \mathrm{gr} \text {. } \\
3 \text { exemplares }\end{array}$ \\
\hline $\begin{array}{l}\text { Gesselschaft Germânia (Rio de } \\
\text { Janeiro) } \mathbf{1 8 7 0}\end{array}$ & Francês & - & - & - \\
\hline $\begin{array}{l}\text { Gesselschaft Germânia (Rio de } \\
\text { Janeiro) } \mathbf{1 8 7 0}\end{array}$ & Alemão & - & - & - \\
\hline $\begin{array}{l}\text { Bibliotheca Rio-Grandense (Rio } \\
\text { Grande) } \mathbf{1 8 7 7}\end{array}$ & Português & - & - & $5 \mathrm{v}$ \\
\hline $\begin{array}{l}\text { Bibliotheca Municipal do Rio de } \\
\text { Janeiro (Rio de Janeiro) } \mathbf{1 8 7 8}\end{array}$ & Português & $\begin{array}{l}\text { Rio de } \\
\text { Janeiro }\end{array}$ & $1844-45$ & $3 v \cdot \ln 8^{\circ}$ \\
\hline $\begin{array}{l}\text { Bibliotheca Municipal de Itaguaí } \\
\text { (Itaguaí) } \mathbf{1 8 8 0}\end{array}$ & Português & - & - & $4 \mathrm{v}$ \\
\hline $\begin{array}{l}\text { Gabinete Português de Leitura da } \\
\text { Bahia (Salvador) } \mathbf{1 8 8 2}\end{array}$ & Francês & Bruxelas & 1844 & $5 \mathrm{v} \cdot \ln 4^{\circ}$ \\
\hline $\begin{array}{l}\text { Gabinete Luso-Brasileiro (Santos) } \\
1882\end{array}$ & Português & - & - & $8 \mathrm{v}$ \\
\hline $\begin{array}{l}\text { Gabinete Português de Leitura de } \\
\text { Pernambuco (Recife) } \mathbf{1 8 8 2}\end{array}$ & Português & Lisboa & $1849-51$ & $5 \mathrm{v} \cdot \ln 8^{\circ}$ \\
\hline
\end{tabular}




\begin{tabular}{|c|c|c|c|c|}
\hline Instituição e data do catálogo & Língua & Local & $\begin{array}{l}\text { Ano da } \\
\text { edição }\end{array}$ & Descrição \\
\hline $\begin{array}{l}\text { Bibliotheca Pelotense (Pelotas) } \\
\mathbf{1 8 9 0}\end{array}$ & Português & - & - & $2 \mathrm{v}$ \\
\hline $\begin{array}{l}\text { Grêmio Literário Português do } \\
\text { Pará (Belém) } 1893\end{array}$ & Francês & - & - & $4 \mathrm{v}$ \\
\hline $\begin{array}{l}\text { Grêmio Literário Português do } \\
\text { Pará (Belém) } 1893\end{array}$ & Português & - & - & $5 \mathrm{v}$ \\
\hline $\begin{array}{l}\text { Bibliotheca Pública de Pernambu- } \\
\text { co (Recife) } 1896\end{array}$ & Português & Porto & $1863-65$ & $4 \mathrm{v} \cdot \ln 16^{\circ}$ \\
\hline $\begin{array}{l}\text { Bibliotheca Pelotense (Pelotas) } \\
\mathbf{1 8 9 8}\end{array}$ & Português & - & - & $4 \mathrm{v}$ \\
\hline $\begin{array}{l}\text { Clube } 11 \text { de Agosto (Desterro) } \\
1901\end{array}$ & Português & - & - & $2 \mathrm{v}$ \\
\hline $\begin{array}{l}\text { Gabinete Português de Leitura da } \\
\text { Bahia (Salvador) } 1902\end{array}$ & Francês & Bruxelas & 1844 & $5 \mathrm{v}$ \\
\hline $\begin{array}{l}\text { Gabinete Português de Leitura da } \\
\text { Bahia (Salvador) } 1902\end{array}$ & Português & Lisboa & - & $4 \mathrm{v}$ \\
\hline $\begin{array}{l}\text { Gabinete Português de Leitura do } \\
\text { Rio de Janeiro (Rio de Janeiro) } \\
1906\end{array}$ & Francês & Bruxelas & 1844 & $\begin{array}{l}\text { 1v. In } 8^{\circ} \mathrm{gr} . \\
\text { Ed. Illustr. }\end{array}$ \\
\hline $\begin{array}{l}\text { Gabinete Português de Leitura do } \\
\text { Rio de Janeiro (Rio de Janeiro) } \\
\mathbf{1 9 0 6}\end{array}$ & Francês & Paris & 1850 & $\begin{array}{l}1 \mathrm{v} . \ln 4^{\circ} \\
\text { Ed. Illustr. }\end{array}$ \\
\hline $\begin{array}{l}\text { Gabinete Português de Leitura do } \\
\text { Rio de Janeiro (Rio de Janeiro) } \\
\mathbf{1 9 0 6}\end{array}$ & Português & Porto & $1863-64$ & $\begin{array}{c}11 \text { t. em } 4 \text { v. } \\
\text { In } 4^{\circ} \\
\text { Nova edição }\end{array}$ \\
\hline $\begin{array}{l}\text { Gabinete Português de Leitura do } \\
\text { Rio de Janeiro (Rio de Janeiro) } \\
1906\end{array}$ & Português & Lisboa & $\mathrm{s} / \mathrm{d}$ & $\begin{array}{l}4 \text { t. em } 2 \text { v. } \\
\quad \ln 4^{\circ}\end{array}$ \\
\hline $\begin{array}{l}\text { Gabinete Português de Leitura do } \\
\text { Rio de Janeiro (Rio de Janeiro) } \\
1906\end{array}$ & Português & $\begin{array}{l}\text { Rio de } \\
\text { Janeiro }\end{array}$ & $\mathrm{s} / \mathrm{d}$ & $\begin{array}{l}4 \text { t. em } 2 \text { v. } \\
\ln 4^{\circ}\end{array}$ \\
\hline $\begin{array}{l}\text { Gabinete Português de Leitura do } \\
\text { Rio de Janeiro (Rio de Janeiro) } \\
\mathbf{1 9 0 6}\end{array}$ & Espanhol & Paris & $1844-45$ & $4 \mathrm{v} . \ln 8^{\circ} \mathrm{gr}$ \\
\hline
\end{tabular}

Os Mistérios de Paris aparecem arrolados em 22 catálogos de 15 instituições distintas, incluindo aí, bibliotecas associativas e bibliotecas públicas provinciais e municipais, cuja dispersão geográfica, desde Belém 
ao Rio Grande, e tamanho do acervo proporcionam bons parâmetros para compreender o sucesso editorial deste romance numa formação sóciocultural tão heterogênea e distante daquele contexto onde originariamente havia sido forjada a obra. O quadro também permite vislumbrar a circulação do romance por meio de edições nacionais (Rio de Janeiro e São Luís) e estrangeiras (Paris, Bruxelas, Londres, Lisboa e Porto), como também a disponibilidade de exemplares publicados na língua original e sob a forma de traduções, neste caso para a língua portuguesa, inglesa, alemã e castelhana. Tudo isso se materializava em padrões gráficos e editoriais expressos por diferentes formatos $\left(\ln 4^{\circ}, \ln 8^{\circ}, \ln 8^{\circ} \mathrm{gr}, \ln 12^{\circ}, \ln 16^{\circ} \mathrm{e}\right.$ In $1^{\circ}$ ) e compostos numa impressionante variedade de número de volumes e tomos combinados entre si. Fato nada desprezível foi constatar que algumas instituições apresentavam mais de um exemplar da mesma edição e que, mesmo sofrendo a voragem do tempo e de seus efeitos sobre um objeto caro e delicado, verificou-se a reposição e aquisição de novos exemplares, certamente para satisfazer a demanda do público.

\section{Da página ao palco}

A leitura da imprensa fluminense também permitiu constatar que o disputado best-seller não apenas foi traduzido e publicado no rodapé do Jornal do Commercio ou ainda sob a forma livro, no Rio de Janeiro e São Luís. Ele adaptado para o teatro sob a forma de drama histórico e representado nos palcos cariocas em três oportunidades, a saber: em 1845 e 1850, no Teatro de São Januário, e ainda em 1851, no Teatro de São Pedro de Alcântara.

A adaptação de textos literários para o palco era uma prática corriqueira. Particularmente, numa sociedade marcada por um restrito sistema de acesso à escolarização e da longeva tradição da leitura de oitiva, a adaptação de romances para a performance dramática teve o importante papel de divulgar temas, personagens e obras que passaram a fazer parte do horizonte cultural de leitores e espectadores.

Como era de praxe, as peças representadas a partir de 1843 no Teatro São Pedro de Alcântara e no Teatro São Januário deveriam ter a chancela do Conservatório Dramático Brasileiro, a quem caberia designar um censor para a elaboração do parecer. ${ }^{29}$ De acordo com os dispositivos prescritos pela direção do Conservatório Dramático, os "censores não devem (deixar) apparecer na scena assumptos, nem mesmo expressões menos conformes o decoro, os costumes e as attenções que em todas as occasiões se devem guardar, maiormente naquellas em que a Imperial Família honrar com a sua

29 Sobre a censura no Conservatório Dramático Brasileiro, veja: KHÉDE, Sonia Salomão. Censores de pincenê e gravata. Rio de Janeiro: Codecri, 1981, esp. p.54-81. Posteriormente, a necessidade do parecer censório passou a ser exigido para apresentações em outros teatros da cidade como o Francês, o de São Francisco, etc. 
Presença o espetáculo" (Aviso de 10/11/1843) ou ainda quando "obras peccarem contra a veneração á nossa Sancta Religião, contra o respeito devido aos Poderes Políticos da Nação e ás Authoridades constituídas, e contra a guarda da moral e da decência publica, a castidade da língua - e aquella parte que he relativa á Orthoepia, pode-se notar os deffeitos, mas não negar a licença." (Resolução Imperial, 28/08/1845). ${ }^{30}$

No que diz respeito à montagem apresentada ao público fluminense em 1845, o processo censório seguiu a tramitação prevista pelos estatutos do Conservatório Dramático. Em ofício dirigido por José Rufino Reis Vasconcelos, $1^{\circ}$ Secretário da instituição, coube ao censor André Pereira Lins a elaboração do parecer sobre a peça ensaiada e dirigida por João Caetano dos Santos. De acordo com a leitura, ele afirmava laconicamente que o texto de Os Mysterios de Paris era

(um) drama romantico original e tirado do romance de mesmo nome de Eugenio Sue (...) na parte somente em que trata da vida de Flor de Maria filha do Príncipe Rodolfo abandonada pela Mãi, muito pouco ressente dos graves deffeitos do mesmo romance, e por isso com certeza se pode dizer que elle não ofende os costumes, nem de maneira alguma sua representação. ${ }^{31}$

A segunda montagem apresentada no Teatro de São Januário em 1850 era anunciada como "novo drama, em 5 actos e 11 quadros" e havia sido ensaiada e dirigida por João Caetano da Silva. A crer na manifestação do presidente do Conservatório Dramático, Diogo Soares da Silva Bivar, "o drama que ora vem a Censura he original e não aquella que foi licenciada". 32 Apesar do alerta de Diogo Bivar, a peça foi liberada, sem obter novo parecer censório.

O reclame publicado nas páginas do Jornal do Commercio fornece alguns elementos interessantes para avaliar a recepção desta montagem prevista para três récitas. O novo drama que "subirá á scena, em primeira representação" incorporava recursos cênicos aparatosos que incidiam no uso do cenário "copiado das gravuras do Theatro da Porte de SaintMartin, e posto em pratica pelo Sr. Antonio Jose Arêas". Outra informação importante acrescida ao anúncio e que poderia mobilizar a imaginação dos espectadores, com especial deferência aos que haviam tomado contato com o texto de Sue, era o fato de que "as personagens irão todas vestidas e caracterisadas tal qual marca o romance". Ainda que a informação possa ser tomada como uma estratégia publicitária, o reclame conclamava aos interessados que "em consequencia de haverem muitas encommendas

30 Tanto o "Aviso", quanto a "Resolução Imperial" são reproduzidos no material que acompanha o parecer de André Pereira Lins (20/03/1845) sobre a representação de Os Mysterios de Paris, no Rio de Janeiro. Fundação Biblioteca Nacional. (FBN) Seção de Manuscritos (SM). Doc. I - 2, 7, 10.

31 FBN. SM. Doc. I-2, 7, 10 Anexo.

32 FBN. SM. Doc. I-8, 6, 66. 
de bilhetes... as pessoas que quizerem prevenir-se...poderão dirigir-se ao escriptorio do theatro a qualquer hora do dia". ${ }^{33}$

A terceira e última menção aos Mysterios de Paris foi obtida por meio de um anúncio publicado na seção "Espetáculos" do Correio Mercantil. Trata-se da mesma montagem exibida no ano anterior, mas desta vez representada no Teatro de São Pedro de Alcântara, integrando as solenidades de aniversário do juramento da Constituição, no dia 25 de março de 1851. ${ }^{34}$ A consulta ao acervo do Conservatório Dramático indica que o diretor da peça, João Caetano da Silva, mais uma vez seguiu as diretrizes estabelecidas pela instituição e solicitou nova licença censória, especialmente pelo fato de que a montagem da peça coincidiria com a Quaresma.

A leitura feita pelo censor Luiz G.J. de Pereira não se restringiu ao exame do texto, mas parecia estar embasada nas projeções da futura montagem, daí ele afirmar:

Esta peça (....) pode ser representada, sem inconveniente, na quaresma. Não Ihe acho scenas interessantes, diálogos bem sustendados, mas é apparatosa em cenário. No theatro de S.Pedro pode produzir bonito effeito.(...) d'esssas peças que chamão muita gente ao theatro, mas que não deixam reminiscencias nos espectadores sensatos. Pode-se representar pelo meu veto. ${ }^{35}$

Desta forma, o parecerista revelava uma percepção aguda de que o êxito da montagem proposta por João Caetano estava fundado na valorização do talento do atores e dos recursos da encenação cujo resultado ele podia deplorar, mas reconhecia os efeitos da ação e das imagens cênicas enquanto elementos mobilizadores da audiência.

O drama histórico foi tão somente uma das modalidades de tradução da linguagem textual do romance para a representação teatral. Ao longo desta investigação verificou-se a existência de ao menos outras três adaptações dos Mistérios de Paris. Ao que tudo indica, duas delas não foram representadas nos palcos brasileiros, a saber: Rodolfo, ação mímica em cinco atos (1858), e I misteri di Parigi, o Fior di Maria, dança em um prólogo e seis partes (1859). ${ }^{36}$

A mais relevante para compreensão da mobilidade do texto de Eugene Sue no Brasil é sem sombra de dúvidas a da ópera cômica Pipelet, nome de um dos personagens dos Mistérios de Paris, composta em três atos, com

33 Jornal do Commercio, Rio de Janeiro, 16/05/1850 n¹30 p.3.

34 Correio Mercantil, Rio de Janeiro, 26/03/1851, p.4. Apud: VITORINO, Artur José Renda. Leitores e leituras de romances franceses em nossas plagas imperiais. Cadernos AEL, Campinas: UNICAMP/IFCH/AEL, n.16/17, v.9, p.80, 2002.

35 FBN. SM. Doc. I-08, 07, 075

36 Respectivamente: Rodolfo, azione mímica in cinque atti di Pasquale Borri da rappresentarsi al Teatro Grande di Brescia nella fiera di agosto 1858; e I misteri di Parigi, o Fior di Maria, ballo romântico in um prólogo e sei parti composto e diretto da Antonio Cortesi da rappresentarsi nel gran Teatro Comunale di Bologna, I'autunno 1859. As duas obras fazem parte do acervo da New York Public Library. 
música do maestro Serafino de Ferrari e libreto de Raffaelle Berninzone. Foi surpreendente constatar que Pipelet foi a primeira experiência de tradução deste gênero por parte do jovem Machado de Assis. A ópera estreou no dia 24 de novembro de 1859, no Teatro São Pedro de Alcântara, sob a direção de José Amat. ${ }^{37}$ No periódico O Espelho, um cronista anônimo anunciava:

Abre-se segunda-feira a Ópera Nacional com o Pipelet, ópera em três atos, música de Ferrari, e poesia do Sr. Machado de Assis, meu íntimo amigo, meu alter ego, a quem tenho muito afeto, mas sobre quem não posso dar opinião alguma. ${ }^{38}$

Antes de fechar a cortina e passar para o tópico seguinte, convém registrar que a ópera cômica Pipelet também foi representada no palco do Teatro São José, na cidade de São Paulo. Ela estreou no dia 06 de setembro de 1884, e marcou o encerramento da temporada lírica da companhia do empresário Vicenzo Tartinis9.

\section{Em busca dos leitores}

Além do registro do processo de tradução e da avidez dos leitores em busca de exemplares do romance ou ainda, da passagem da leitura silenciosa e individual do romance para a performance dramática nos palcos da cidade do Rio de Janeiro, obtive dois registros que mencionam os efeitos da leitura e a sua transformação em matéria de rememoração.

O primeiro deles foi Nicolau Antônio Nogueira Vale da Gama, que ocupou o posto de veador da Imperatriz. Em correspondência datada de 07/06/1855 e remetida de Paris para o seu filho que cursava o primeiro ano da Faculdade de Direito de São Paulo, ele relatava a sua primeira viagem à capital francesa, onde acompanhava a delegação brasileira na Exposição Universal da Indústria. Vale da Gama informa ter se encarapitado no ponto mais alto de uma das torres da catedral de Notre Dame, e

dali penetrei a vista por todos aqueles becos sombrios e tortuosos na ilha, onde existem a magnífica Basílica e o Palácio da Justiça, e que é o mais antigo bairro desta cidade denominada Cité, de que fala Eugène Sue, nos seus Mistérios de Paris. Percorri-os depois, um por um, até encontrar o n³ da rua das Favas, rue aux Fèves, e outros em que se passaram, segundo a fertilíssima imaginação do leitor, as cenas de Rodolfo, da Gueladeira, do Churinada, do Lobisomem, da Coruja, do Mestre-Escola, do Gambeta 8. Destinarei um dia para visitar com

37 Cf. MAGALHÃES JUNIOR, Raimundo. Machado de Assis desconhecido. Rio de Janeiro: Ed. Civilização Brasileira, 1957, p.412

38 Apud: MASSA, Jean-Michel. A juventude de Machado de Assis. Rio de Janeiro: Ed. Civilização Brasileira, 1971, p.266.

39 Cf. AMARAL, Antônio Barreto do. História dos velhos teatros de São Paulo. São Paulo: Governo do Estado, 1979, p.114. 
mais vagar todas as espeluncas, que realmente existem, e tão hediondas como o romancista as descreve. ${ }^{40}$

Finalmente, nas páginas de Baú de Ossos, obra memorialística de Pedro Nava, foi possível colher esta referência preciosa que mostra o trânsito da obra pelas bibliotecas privadas e a sua presença fugaz na imaginação dos leitores contemporâneos. Ao recompor a trajetória dos livros que inicialmente compunham a biblioteca do marido de sua avó e que depois de três gerações encontravam-se sob sua guarda, Nava registrou com pesar:

Os livros que eu conheci, quando menino e que restavam em nossa casa de Juiz de Fora, os dois volumes à tranches dorées, do romance de Eugène Sue, Mathilde (...) O Rei, a Corte, os palácios, os castelos. Que tempo, que gente... Tempo em que Eugène Sue era mais conhecido e considerado maior escritor que Balzac. E quem se lembra hoje de Mathilde, de Le Juif Errant, de Les Mystères de Paris? E até do nome do autor desses rocamboles? ${ }^{41}$

40 GAMA, N.A.N.V. "Memórias" de Nogueira da Gama. In: CALMON, Pedro. História de Minas e "Memórias" de Nogueira da Gama. Rio de Janeiro: José Olympio/INL, 1985, p.116-117.

41 NAVA, Pedro. Baú de ossos. Rio de Janeiro: José Olympio, 1974, p.17. 